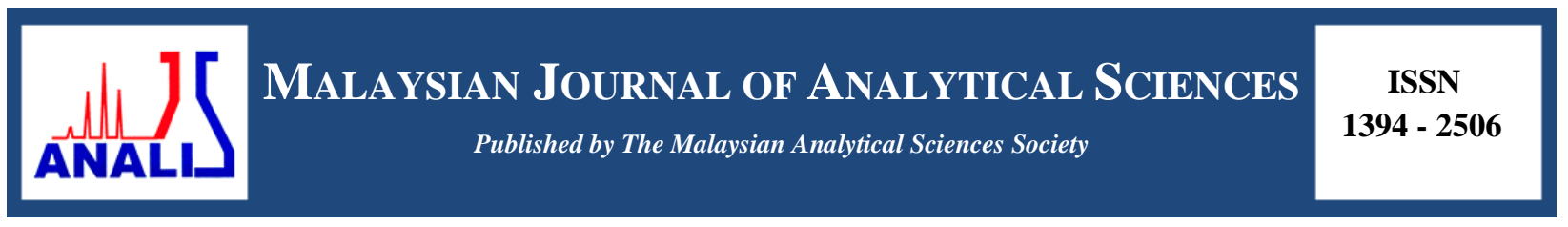

\title{
ISOLATION AND PURIFICATION OF LYSOZYME FROM ALBUMIN: EFFECT OF ALBUMIN CONCENTRATION, pH AND IONIC STRENGTH OF BUFFER SOLUTION
}

\author{
(Pemisahan dan Penulenan Lisozim dari Albumin: Kesan Kepekatan Albumin, pH dan Kekuatan \\ Ionik Larutan Penimbal)
}

\author{
Amirah Hamzah ${ }^{1}$, Sofiah Hamzah ${ }^{1}$, Fatin Mohd Nasir ${ }^{1}$, and Marinah Mohd Ariffin ${ }^{2}$ \\ ${ }^{1}$ School of Ocean Engineering \\ ${ }^{2}$ School of Marine Science and Environment \\ Universiti Malaysia Terengganu, 21030 Kuala Terengganu, Terengganu, Malaysia
}

*Corresponding author: sofiah@umt.edu.my

Received: 24 February 2015; Accepted: 27 October 2015

\begin{abstract}
The low content of lysozyme in albumin makes its purification process becomes complicated and challenge either in lab or industrial scale system. This study aimed to investigate the parameters influencing the purification performance lysozyme from chicken egg white (CEW) namely initial concentration of albumin, $\mathrm{pH}$ and ionic strength of buffer solution. Immobilized metal affinity chromatography (IMAC) beads were prepared using chitosan-coated silica beads which then crosslinked with glutaraldehyde (GTA) and reacted with metal ion copper $(\mathrm{Cu})$ for metal ion immobilization to be used as purification tools. The prepared beads were characterized in term of morphology and structure using scanning electron microscope (SEM). Column chromatographic has been utilized for evaluation performance of IMAC for lysozyme separation. Optimum recovery obtained using $20 \mathrm{mg} / \mathrm{ml} \mathrm{CEW} \mathrm{concentration} \mathrm{at} \mathrm{pH} \mathrm{7,} \mathrm{with} 0.05 \mathrm{M}$ ionic strength. The finding of this study exhibited a good pathway to design an affinity system for lysozyme purification either from chicken egg white or other sources in the future.
\end{abstract}

Keywords: lysozyme, chicken egg white, purification, $\mathrm{pH}$, ionic strength, affinity chromatography

\begin{abstract}
Abstrak
Kandungan lisozim yang rendah di dalam albumin membuatkan proses penulenan menjadi semakin rumit dan mencabar sama ada sistem di makmal atau industri. Kajian ini bertujuan untuk mengoptimumkan parameter yang mempengaruhi prestasi penulenan lisozim dari albumin iaitu kepekatan awal albumin, $\mathrm{pH}$ dan kekuatan ionik larutan penimbal. Kromatografi affiniti logam pegun telah disediakan dengan menggunakan silika yang bersalut kitosan yang kemudiannya diaktifkan menggunakan glutaraldehid (GTA) serta bertindak balas dengan ion logam kuprum bagi pemegunan ion logam (kuprum) untuk digunakan sebagai alat penulenan. Pencirian silika telah dilakukan dari segi morfologi dan struktur dengan menggunakan mikroskop elektron pengimbas (SEM). Kolum kromatografi digunakan untuk menilai prestasi IMAC bagi pemisahan lisozim. Penghasilan yang optimum diperolehi dengan menggunakan $20 \mathrm{mg} / \mathrm{ml}$ kepekatan putih telur pada $\mathrm{pH} 7$ dengan kekuatan ionik sebanyak 0.05 M. Hasil kajian ini menunjukkan cara yang baik untuk mereka bentuk sistem affiniti untuk penulenan lisozim sama ada daripada sumber putih telur atau sumber lain pada masa akan datang.
\end{abstract}

Kata kunci: lisozim, albumin, penulenan, pH, kekuatan ionik, kromatografi affiniti 


\section{Introduction}

For many decades, chicken egg white (albumin, abbreviation as CEW) have been used as the subject of study for chemical, biochemical and food technological research because of the importance in human for food supply and also the potential use in biotechnology processes. Chicken egg white is the cheapest source for production of enzyme such as lysozyme using protein fractionation. Industrial application often restricted by the difficulty of recovery and reuse of the enzyme as well the lack of long-term operational stability. In order to overcome the problems, techniques that been applied in the laboratories for the separation of lysozyme from chicken egg white protein which are centrifugation, electrophoresis and chromatography [1]. Moreover, the isolation and purification process of the lysozyme becomes complicated and challenges due to the low content of the lysozyme in the chicken egg white. It is required to apply the effective and large scale protein purification process for lysozyme purification [2]. For the reason, a large quantity of the raw materials from chicken egg white needed in order to get the rational amount of pure lysozyme.

Protein separation and purification using immobilized metal affinity chromatography (IMAC) silica beads has become a powerful technique due to the inexpensive cost, ease of preparation as well high adsorption capacity [3]. The optimize purification conditions are needed to achieve both high yield and purity of the enzyme [4]. Thus, the important parameters of the physico-chemical environment of the feed solution that affect the separation process of lysozyme from chicken egg white such as $\mathrm{pH}$ of buffer solution, ionic strength and initial chicken egg white concentration that have been studied using affinity column chromatography as an alternative separation technique which is can be fine tuned to achieve high productivity in protein separation process. However, for the enzyme activity of the lysozyme, it was indicated using Micrococcus lysodeikticus as the substrate. The addition of $M$. lysodeikticus to the lysozyme solution in order to detect the enzyme activity that causes the decrease in the optical density. One lysozyme unit was defined as the amount of enzyme causing a decrease of 0.001 per minute in the absorbance at $450 \mathrm{~nm}$ where the suspension of $1 \mathrm{mg} / \mathrm{ml}$ M. Lysodeikticus as the substrate in $1 \mathrm{ml}$ reaction mixture.

Thus, the aim of this research is to provide a new efficient and low cost technique for industrial manufacturing of purified lysozyme from raw chicken egg white using IMAC bead.

\section{Chemicals and Materials}

\section{Materials and Methods}

All materials used during the conduct of research are of analytical grades. Lysozyme and chicken egg white are purchased from Sigma Chemical Company. All other chemicals were guaranteed or analytical grade reagents commercially available and used without further purification.

\section{Immobilized metal affinity chromatography beads preparation}

In this study, chitosan-coated silica beads which then crosslinked with glutaraldehyde (GTA) and reacted with metal ion copper $(\mathrm{Cu})$ for metal ion immobilization been used as IMAC support. Preparation of chitosan-coated silica beads was according to Shi et al. [5] with some modification. Silica gel were washed with $20 \%$ hydrochloric acid solution for 8 hours and been dried at $40{ }^{\circ} \mathrm{C}$ before immersed into distilled water to wet the pore surface. Then, the silica gel was immersed into chitosan solution ( $0.1 \mathrm{wt}$. \% in acetic acid pH 5) for 72 hours for surface coating. The chitosan-coated silica gel then added to $\mathrm{NaOH}$ solution for 2 hours and being washed with distilled water before crosslinking the beads with glutaraldehyde (GTA) for 16 hours in incubator shaker. The activated chitosan-silica beads were reacted with metal ion $\left(\mathrm{CuSO}_{4}\right)$ for 24 hours and kept in the distilled water for storage and been called immobilized metal affinity chromatography (IMAC) beads. Then, the IMAC beads were characterized using scanning electron microscope (SEM) for the morphology and structure study. The IMAC samples were coated with gold before transferred under microscope.

\section{Lysozyme purification from chicken egg white and activity measurements}

Chromatographic studied were carried out on IMAC beads using affinity column chromatography according to Ai et al. [6] with some modification. Thus, for the study of the feed solution, there were three factors being identified for the purification process of the lysozyme such as $\mathrm{pH}$ of buffer solution, ionic strength and initial CEW concentration. The optimize purification conditions are needed to achieve both high yield and purity of the enzyme as well. The column was equilibrated with $50 \mathrm{~mL}$ of phosphate buffer solution. Chicken egg white solution prepared with the 
same buffer solution was bumped into the column at a constant volume velocity of $1.0 \mathrm{~mL} / \mathrm{min}$ for five hours. When the adsorption of the $\mathrm{CEW}$ was saturated, the column been washed with $50 \mathrm{~mL}$ of same buffer solution to eliminate unbound proteins. The lysozyme adsorbed on the column was eluted by using a mixture solution of $0.3 \mathrm{M}$ imidazole and $0.25 \mathrm{M} \mathrm{NaCl}$ in $0.01 \mathrm{M}$ phosphate buffer $(\mathrm{pH}$ 6.0). The final lysozyme concentration in elution medium was determined spectrophotometrically using Bradford method [7].

\section{Determination of total protein}

The detection and quantitation of the total protein has been detected using Bradford assay method [7] while bovine serum albumin (BSA) has been used as the standard. Different dilutions of BSA standard solutions were prepared by mixing BSA stock solution $(1 \mathrm{mg} / \mathrm{mL})$ and phosphate buffer. The absorbance and concentration were analyzed using UV -Vis spectrophotometer at $595 \mathrm{~nm}$ by dissolving every $100 \mu \mathrm{L}$ sample with $3 \mathrm{~mL}$ Bradford reagent. The absorbance against protein concentration was plotted to obtain a standard calibration curve. The analysis was repeated using the lysozyme obtained from CEW as the sample.

\section{Lysozyme activity measurement}

Lysozyme activity was determined by its lytic action on Micrococcus lysodeikticus cell suspended in the phosphate buffer. One lysozyme unit was defined as the amount of enzyme causing a decrease of 0.001 per minute at $25{ }^{\circ} \mathrm{C}$ and $\mathrm{pH} 7.0$ in the absorbance at $450 \mathrm{~nm}$ where the suspension of $2.9 \mathrm{~mL}$ of M. Lysodeikticus as the substrate mixed with $0.1 \mathrm{~mL}$ of diluted lysozyme.

\section{IMAC characterization}

\section{Results and Discussion}

IMAC beads have been used as one of the successful processes for isolation and purification of the proteins as well enzymes. It was immobilized with $0.1 \mathrm{M}$ concentration of metal ions and high amount of enzyme loading can be applied to obtain high yield of lysozyme recovery. Thus, the process also allow for the easy product elution and metal ions regeneration [3].

Figure 1 shows the surface morphology of (a) silica gel and (b) IMAC adsorbent using scanning electron microscope (SEM) with 5000x enlargement. The silica have uneven surface that made it easier to bind with chitosan, glutaraldehyde activator and metal ion copper $\left(\mathrm{Cu}^{2+}\right)$ as the IMAC adsorbent. The silica that being crosslinked using glutaraldehyde to stabilize the surface of silica for metal ion immobilization [8]. It also provided the best surface area for the enzyme binding and eluted during affinity chromatography of the lysozyme from CEW.
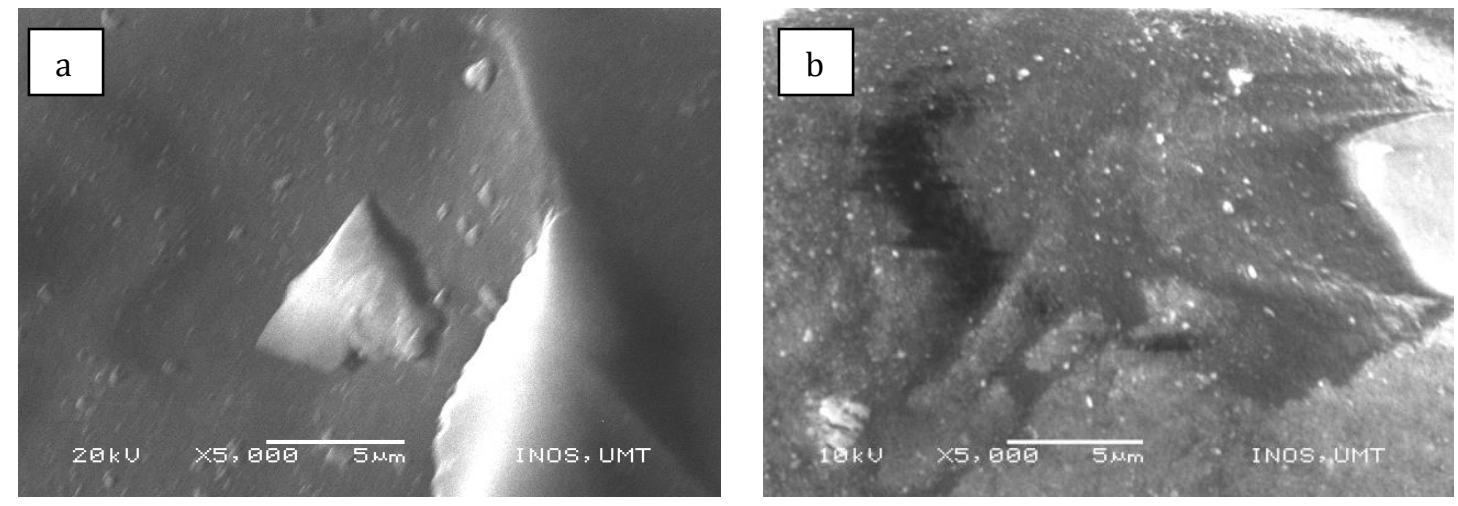

Figure 1. Surface morphology of (a) Silica gel and (b) IMAC adsorbent

\section{Effect of CEW solution concentration, $\mathrm{pH}$ and ionic strength of buffer solution}

The content of the lysozyme in chicken egg white was about $3.4 \%$ [9] making its purification process becomes complicated. There are some factors that influenced the performance of the lysozyme from CEW which were concentration of the $\mathrm{CEW}$ solution, $\mathrm{pH}$ and ionic strength of buffer solution. The effects of CEW concentration on 
lysozyme separation and purification from IMAC beads was studied using CEW concentration ranged from $5 \mathrm{mg} / \mathrm{mL}$ to $25 \mathrm{mg} / \mathrm{mL}$ of CEW in buffer solution. The results obtained displays in Figure 2 (a) and (b) and there was a remarkable change in the purity of lysozyme even there were only slight difference in the yield obtained.
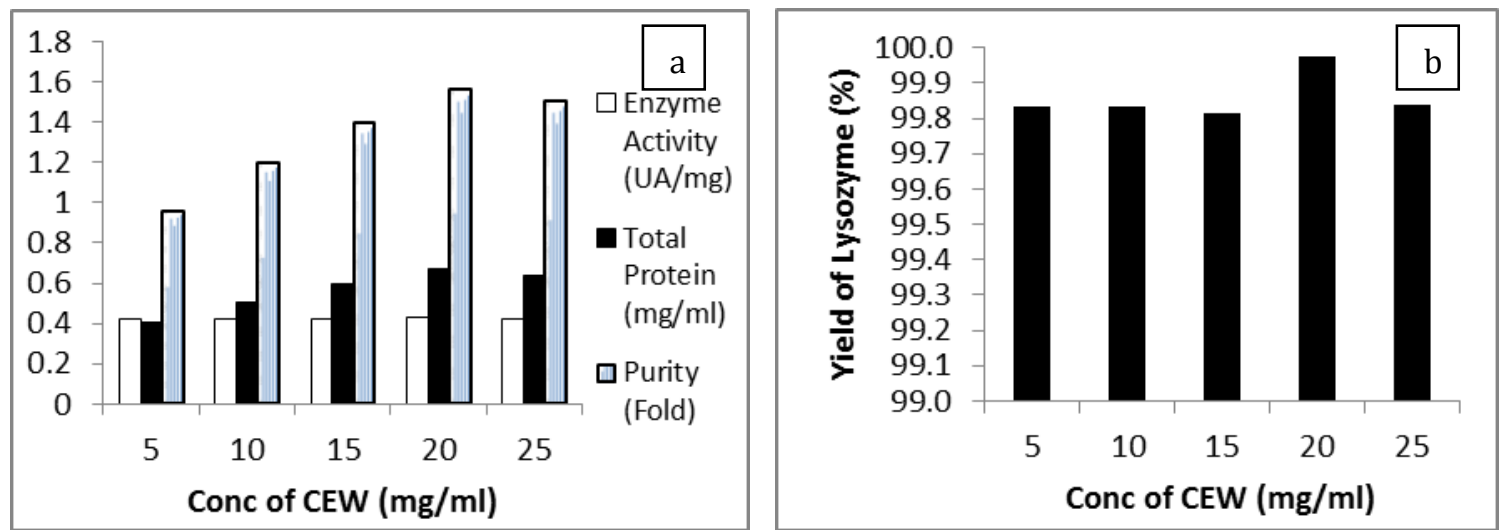

Figure 2. Affinity column chromatography with different concentration of CEW solution (a) enzyme activity, total protein, purity of lysozyme and (b) yield of lysozyme

The highest lysozyme recovery $(99.97 \%$ ) obtained using $20 \mathrm{mg} / \mathrm{mL}$ initial concentration of CEW where the specific activity of lysozyme and total protein concentration in the feed solution were assayed at $0.42 \mathrm{UA} / \mathrm{mg}$ and $0.67 \mathrm{mg} / \mathrm{ml}$ as well with 1.56 of purification fold. This promising result was due to the equilibrium phase of the CEW concentration at $20 \mathrm{mg} / \mathrm{mL}$ and the further increase of initial concentration $(25 \mathrm{mg} / \mathrm{mL})$ did not improve the separation performance since all the active site of IMAC beads had been bound with lysozyme.

The increasing of the CEW concentration from $5 \mathrm{mg} / \mathrm{mL}$ to $20 \mathrm{mg} / \mathrm{mL}$ had been promoting the adsorption of enzyme from the surface of IMAC beads and gave higher recovery (yield) of lysozyme. While the concentration of CEW was about $5 \mathrm{mg} / \mathrm{mL}$, the specific activity of lysozyme was also $0.42 \mathrm{UA} / \mathrm{mg}$ but the recovery of lysozyme was about $99.81 \%$. Overall, the initial concentration used in this study promoted very outstanding result when more that $99 \%$ lysozyme can be recovered. This finding can be explained due to the cooperative effect of different interaction mechanisms such as hydrogen bonding, electrostatics and hydrophobic cause by the buffer in the CEW and IMAC beads as well [10].

Figure 3 shows the effects of $\mathrm{pH}$ of the buffer solution on the adsorption capacity of lysozyme onto IMAC beads, whereas the best recovery occurred at $\mathrm{pH} 7$ when the specific activity of lysozyme and total protein concentration in the feed solution were about $0.41 \mathrm{UA} / \mathrm{mg}$ and $0.33 \mathrm{mg} / \mathrm{ml}$ with 0.81 purification fold. At this rate, $\mathrm{pH} 7 \mathrm{had}$ promoted very high yield recovery of lysozyme which about $99.85 \%$. The $\mathrm{pH}$ of buffer solution provide great effect for the recovery of the lysozyme from CEW since the changes of the solution $\mathrm{pH}$ can be altered the electrical charge on the lysozyme as well. The isoelectric point (IEP) of lysozyme was around 11 and at $\mathrm{pH}$ value below the IEP, the lysozyme adsorbed was clearly higher than at $\mathrm{pH}$ values above the IEP. At $\mathrm{pH} 7$, lysozyme would be cationic since this $\mathrm{pH}$ was below than its isoelectric point. This $\mathrm{pH} 7$ was served as a good environment for the lysozyme with the help of electrostatic interaction that has been predominant for recovery of the enzyme from CEW.

At $\mathrm{pH} 5$, the purification capacity of lysozyme was the lowest which about $0.38 \mathrm{UA} / \mathrm{mg}$ of lysozyme specific activity with its yield were $95.23 \%$. This result indicated that the capability of lysozyme coordination with the IMAC beads was not necessarily suitable in acidic condition. This occurrence might result from the protonation of electron donor group in lysozyme molecule, leading to decreasing coordination ability with metal ions [11]. Furthermore, lower performance at the $\mathrm{pH}$ approaches IEP of lysozyme at $\mathrm{pH} 9$ was due to the instability 
occurrence. This result can be explained as the percentage of $\mathrm{HPO}_{4}{ }^{2}$ - and $\mathrm{PO}_{4}{ }^{3-}$ in buffer solution which acquired a relative higher metal coordinating ability compared to $\mathrm{HPO}_{4}^{-}$. This condition would compete with lysozyme for metal binding and increased in alkali condition [12]. Due to lysozyme isoelectric point which at $\mathrm{pH} 11$, lysozyme specific activity just about $0.43 \mathrm{UA} / \mathrm{mg}$ and its yield that has been recovered from IMAC beads was about $99.01 \%$. This result might be explained due to the protein aggregation [13] since the lysozyme surface net charge was zero, thus there were no electrostatic repulsive force being effective between the lysozyme molecules at this $\mathrm{pH}$.
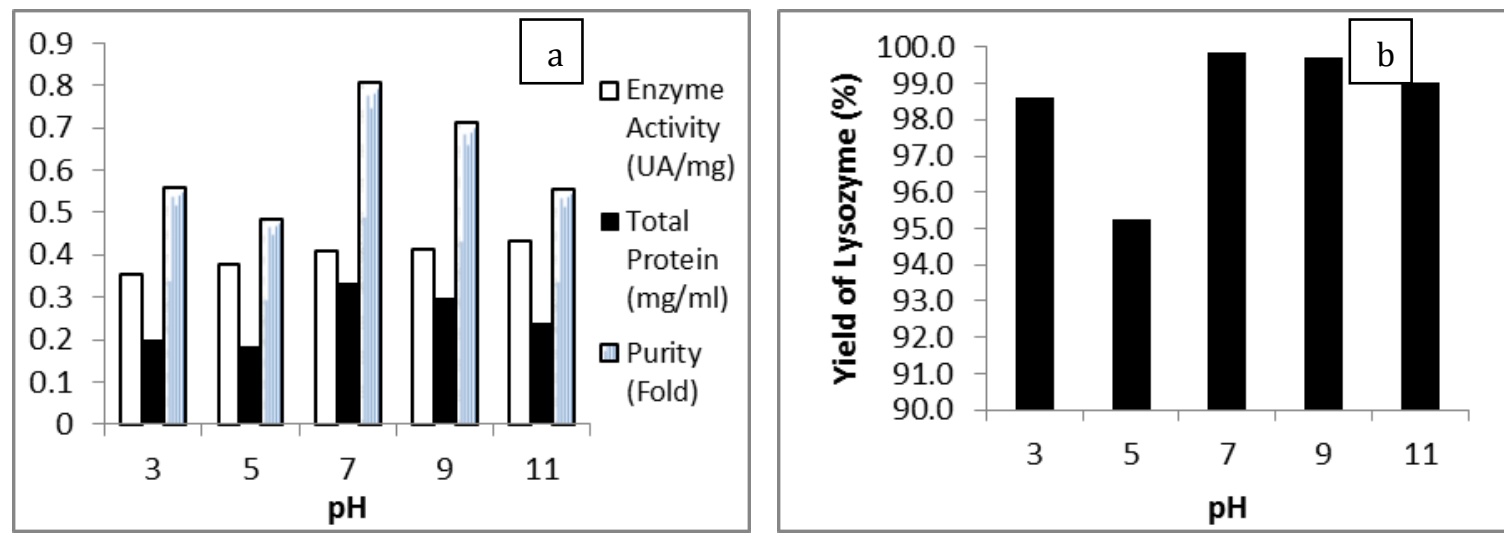

Figure 3. Affinity column chromatography with different $\mathrm{pH}$ of buffer solution (a) enzyme activity, total protein, purity of lysozyme and (b) yield of lysozyme

The effect of ionic strength was studied using the CEW solution with a fixed $\mathrm{pH} 7$ since the previous observation determined that $\mathrm{pH} 7$ successfully promoted the best recovery of lysozyme. Since the IMAC beads were highly charged with electrolyte, the effects of ionic strength on lysozyme separation and purification from CEW was studied using addition of $\mathrm{NaCl}$ from $0.01 \mathrm{M}$ to $0.09 \mathrm{M}$. The results obtained were displayed in Figure 4 (a) and (b) where there was a significant change in the lysozyme recovery through the change in ionic strength of the buffer solution. For the effects of ionic strength, the results that been achieved the best when $\mathrm{NaCl}$ was $0.05 \mathrm{M}$ with the $0.33 \mathrm{UA} / \mathrm{mg}$ lysozyme specific activity and $0.29 \mathrm{mg} / \mathrm{ml}$ of total protein concentration in the feed solution. While the yield of the lysozyme was about $99.24 \%$ with 0.89 purification fold. It was due to the high lysozyme being eluted from CEW.
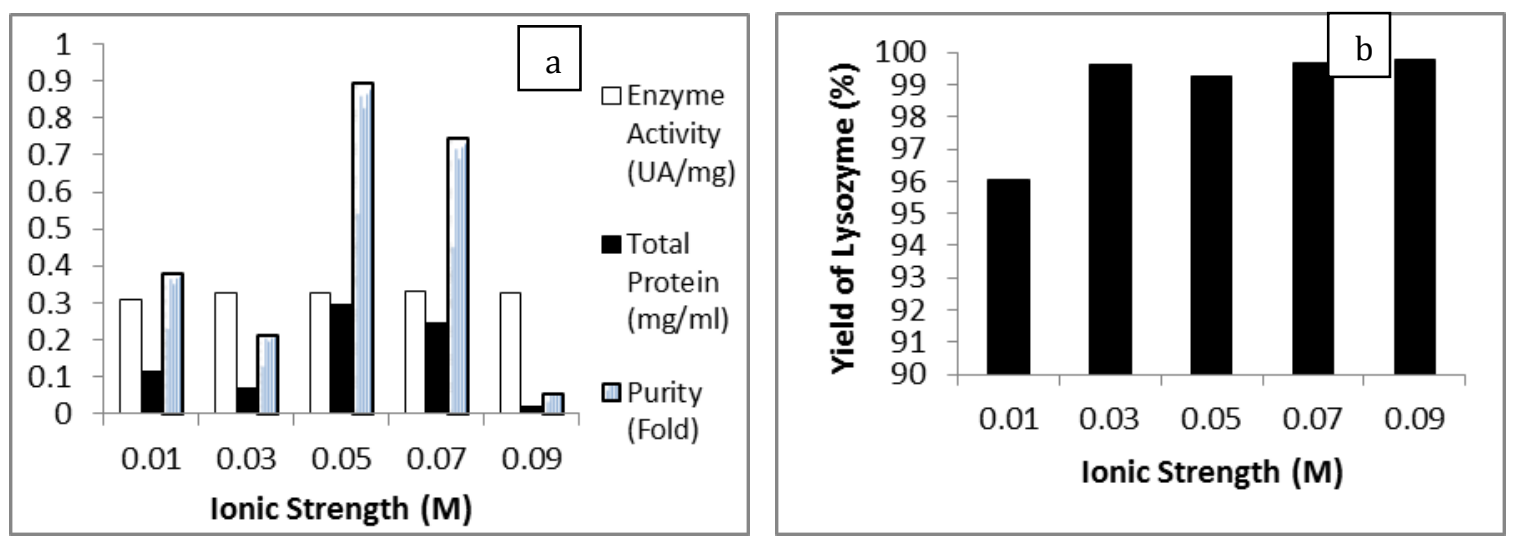

Figure 4. Affinity column chromatography with different ionic strength of buffer solution (a) enzyme activity, total protein, purity of lysozyme and (b) yield of lysozyme 
Otherwise, when the $\mathrm{NaCl}$ was at $0.03 \mathrm{M}$, the specific activity of lysozyme was about $0.32 \mathrm{UA} / \mathrm{mg}$ and $0.06 \mathrm{mg} / \mathrm{ml}$ of total protein concentration in the feed solution. Meanwhile the yield of the lysozyme was obtained at $99.6 \%$. Although the yield of lysozyme when the $\mathrm{NaCl}$ concentration about $0.03 \mathrm{M}$ higher than the concentration at $0.05 \mathrm{M}$, but the purification fold was just 0.21 . It shows that the concentration of $0.05 \mathrm{M} \mathrm{NaCl}$ have the highest purity rather than concentration of $0.03 \mathrm{M}$. The increasing of the $\mathrm{NaCl}$ concentration from $0.01 \mathrm{M}$ to $0.05 \mathrm{M}$ had been encouraged the recovery of the enzyme from the surface of IMAC beads. Then, the hydrophobic interactions among them become strong. Furthermore, the addition of $\mathrm{NaCl}$ more than $0.05 \mathrm{M}$ caused the recovery capacity to reduce since the ionic strength had affects the chelating bonding of lysozyme on both metal affinity carriers [14]. Besides, in high ionic strength buffer, protein solubility usually reduces which were salt-out effect due to the decreasing activity of water and the neutralization of surface charge. These conditions also assist the formation of protein aggregates, leading to the decrease in lysozyme adsorption onto IMAC beads and reduce the purification of the lysozyme itself.

\section{Conclusion}

The process developed using IMAC beads allows the recovery and purification of the lysozyme from chicken egg white (CEW) with high recovery capacity of matrix at low cost and high efficiency. This study proved that concentration of $\mathrm{CEW}, \mathrm{pH}$ and ionic strength of buffer solution significantly influenced the purification process of the lysozyme from CEW. The most optimum lysozyme recovery was at $20 \mathrm{mg} / \mathrm{mL}$ of CEW concentration in buffer solution at $\mathrm{pH} 7$ and ionic strength of $0.05 \mathrm{M}$. Affinity chromatography using IMAC beads was a potential alternative for industrial purposes.

\section{Acknowledgement}

The authors would like to express their sincere gratitude to the Ministry of Education, for the grant of the Exploratory Research Grant Scheme (ERGS) and high appreciation to School of Ocean Engineering and Central Laboratory, University Malaysia Terengganu for the cooperation and support.

\section{References}

1. Muller, A., Daufin, G. and Chaufer, B. (1999). Ultrafiltration modes of operation of $\alpha$-lactalbumin from acid casein whey. Journal of Membrane Science, 153: 9 - 21.

2. Wan, W. H., Lub, J. R., and Cui, Z. F. (2006). Separation of lysozyme from chicken egg white using ultrafiltration. Separation and Purification Technology, 48: 133 - 142.

3. Yilmaz, M., Bayromoğlu, G. and Arica, M. Y. (2005). Separation and purification of lysozyme by Reactive Green 19 immobilised membrane affinity chromatography. Food Chemistry, 89: 11 - 18.

4. Shin, H. S. and Cha, H. J. (2003). Statistical optimization for immobilized metal affinity purification of secreted human erythropoietin from Drosophila S2 cells. Protein Expression and Purification, 28: 331 - 339.

5. Shi, Q. H., Tian, Y., Dong, X. Y., Bai, S. and Sun, Y. (2003). Chitosan-coated silica beads as immobilized metal affinity support for protein adsorption. Biochemical Engineering Journal, 16: 317 - 322.

6. Lu, A. X., Liao, X. P., Zhou, R. Q. and Shi, B. (2007). Preparation of Fe(III)-immobilized collagen fiber for lysozyme adsorption. Colloids and Surfaces A: Physicochemical Engineering Aspects, 301: 85 - 93.

7. Kruger, N. J. (2002). The protein protocols handbook, second edition: the Bradford method for protein quantitation. Humana Press, pp. 15 - 21.

8. Guo, W. and Ruckenstein, E. (2003). Separation and purification of horseradish peroxidise by membrane affinity chromatography. Journal Membrane Science, 211: $101-111$.

9. Ghosh, R., Sudarshana, S. S. and Cui, Z. F. (2000). Lusozyme separation by hollow-fibre ultrafiltration. Biochemical Engineering Journal, 6: $19-24$.

10. Evrim, B. A. and Adil, D. (2006). Monosize poly(glycidyl methacrylate) beads for dye-affinity purification of lysozyme. International Journal of Biological Macromolecules, 38: 99 - 106.

11. Sun, Y., Liu, Y., Li, Y., Lv., M., Li, P., Xu, H. and Wang, L. (2011). Preparation and characterization of novel curdlan/chitosan blending membranes for antibacterial applications. Carbohydrate Polymers, 84: 952 - 959.

12. Hamzah, S., Nasir, F. M and Hamzah, A. (2014). Lysozyme adsorption onto immobilised metal affinity chromatographic adsorbent: effect of $\mathrm{pH}$ and ionic strength. International Journal of Applied Engineering Research, 9: 17783 - 17792. 
13. Gustafsson, C., Thorn, C. and Holmberg, K. (2011). A comparison of lipase and trypsin eccapsulated in mesoporous materials with varying pore sizes and $\mathrm{pH}$ conditions. Colloids and Surfaces B: Biointerfaces, 87: $464-471$.

14. Muller, C.H., Agarwal, G.P., Melin, T. and Vintgens, T. (2003). Study of UF of single and binary protein solution in a thin spiral channel module. Journal of Membrane Science, 227: 51 - 69. 